\title{
Insights into Common Microdeletion Syndromes
}

\author{
Sathiya Maran ${ }^{1}$, Mehboob Alam Pasha ${ }^{2}$ and Thirumulu Ponnuraj Kannan ${ }^{1,3}$ \\ ${ }^{1}$ Human Genome Centre, School of Medical Sciences, Universiti Sains Malaysia 16150 Kubang Kerian, \\ Kelantan, Malaysia \\ ${ }^{2}$ Department of Surgery, School of Medical Sciences, Universiti Sains Malaysia 16150 Kubang Kerian, \\ Kelantan, Malaysia \\ ${ }^{3}$ School of Dental Sciences, Universiti Sains Malaysia 16150 Kubang Kerian, Kelantan, Malaysia
}

\begin{abstract}
Microdeletion syndromes are due to submicroscopic chromosomal deletions and display a complex clinical and behavioral phenotype. This occurs because of an imbalance of normal dosage of genes that are present in that segment of chromosome. Many clinical characteristics of the well-known microdeletion syndromes are very specific and have been well defined. It is not always possible to detect these microdeletions by using the conventional or high resolution karyotyping. This necessitates the application of molecular cytogenetic techniques and the recent widespread usage and an in-depth knowledge of methods such as G-band karyotyping, multiples ligation-dependent probe amplification (MLPA), quantitative fluorescent $P C R(Q F$ $P C R$ ), sequencing and microarray-based comparative genomic hybridization (array $C G H$ ) had further led to identification of new microdeletions and sound description of identification of new microdeletion syndromes. This review appraises the common microdeletion syndromes focusing on the incidence rate, clinical manifestations and the mechanism involved therein.
\end{abstract}

Keywords: Clinical Features, Detection methods, Incidence rate, Microdeletion Syndromes

\section{Introduction}

Microdeletion syndromes are defined as a group of clinically recognizable disorders which are characterized by a small $(<5 \mathrm{Mb})$ deletion of a chromosomal segment spanning multiple disease genes, each potentially contributing to the phenotype independently [1]. Alongside, the recent explosion in the implementation of genome-wide microarray technology to discover rare, pathogenic genomic rearrangements in a variety of diseases has led to the discovery of numerous microdeletion syndromes [2]. These microdeletions are associated with extensive phenotypic heterogeneity and incomplete penetrance. The recurrent microdeletion had been reported to underpin diverse phenotypes, including intellectual disability, autism, epilepsy and neuropsychiatric disorders [2].

The Contiguous Gene syndromes in 1986 defined by Schmickel was the first to give rise to the 'microdeletion syndromes' which involved the deletion of a contiguous stretch of DNA, including multiple genes, on a chromosome [3].These syndromes are clinically recognized with distinct physical, behavioural, and mental characteristics and often involve some individual features that can be inherited in a Mendelian fashion [3].

The common microdeletion syndromes that have been reported till date are Smith-Magenis Syndrome, Miller-Dieker Syndrome, Prader-Willi Syndrome, Angelman Syndrome, Velocardiofacial Syndrome and DiGeorge Syndrome and Williams Syndrome [3] , which has been summarized in Table 1.

\subsection{Smith-Magenis Syndrome}

\section{Microdeletion Syndromes}

Smith-Magenis syndrome (SMS) is caused by the microdeletion at $17 \mathrm{p} 11.2$ and has been reported with an incidence rate of 1 in 25,000 births [3]. Clinical manifestations of SMS are craniofacial and skeletal anomalies, neurobehavioral abnormalities such as sleep disturbance and seizures, ophthalmic anomalies, otolaryngologic anomalies, cardiac and renal anomalies [4]. The major phenotypes of SMS are distinctive craniofacial features including brachycephaly, a broad face, frontal bossing, synophrys, hypertelorism, upslanting eyes, midface hypoplasia with a depressed nasal bridge, a tented upper lip, prognathism, and low-set or abnormally shaped ears $[5,6]$.

SMS is associated with deletion and mutation on the RAI1 gene located at chromosome 17p11.2 [7] Majority of the patients (75-90\%) harbour a $\sim 4 \mathrm{Mb}$ deletion [8-10]. Meanwhile, patients with smaller deletions show deletion of about 20 genes [11]. The SMS phenotype is variable even in patients with deletions of the same size [9]. Although the exact mechanism of SMS has yet to be elucidated, abnormalities in the expression of SREBF1, MYO15, COPS3, PMP22 and other genes may also contribute to the specific clinical features, elevated cholesterol levels, peripheral neuropathy, hearing loss and abnormal sleep patterns [12-16]. The 
diagnosis of SMS is based on initial clinical suspicion such as onychotillomania (mutilation of fingers and toe nails) polyembolokoilamania (insertion of foreign objects into body orifices), followed by molecular confirmation of chromosome 17p11.2 deletion using FISH probes [16].

\subsection{Miller-Dieker Syndrome}

Miller-Dieker syndrome (MDS) (MDS; MIM \#247200) is a rare contiguous 17p13.3 deletion with an incidence rate of $\sim 1 / 50,000$ births [3] . Patients with MDS exhibit severe grade of lissencephaly and display a characteristic dysmorphic facial appearance [17]. This includes prominent forehead with bitemporal hollowing, short nose with upturned nares and thickened upper lip with a thin vermilion upper border, widely spaced eyes, low ears, and small jaw. MDS has been associated with other abnormalities, including central hypotonia, heart malformations, omphalocele, inguinal hernia, duodenal atresia, pelvic and cystic kidneys, sacral tails, cryptorchidism, polydactyly, clinodactyly, camptodactyly, transverse palmar creases and polyhydramnios during pregnancy [18]. These patients also exhibit mental and motor impairment, epilepsy and a reduced life span [17] .

The phenotypes observed in MDS are largely due to haploinsufficiency of LISI and YWHAE [19]. The 17 p13.3 deletion occurs due to a number of mechanisms including recombination of a parental balanced translocation or inversion of chromosome 17, a ring chromosome 17, or by a de novo deletion [17]. MDS is commonly diagnosed by fluorescence in situ hybridization (FISH) [20].

\subsection{Prader-Willi Syndrome}

Prader-Willi syndrome (PWS) is a genetic disorder, with a prevalence of $1 / 10,000-1 / 30,000$, resulting from lack of expression of genes on the paternally inherited chromosome 15q11.2-q13 [21].Although, neurocognitive abnormalities have been well-established in PWS, the pathophysiology leading to the clinical findings remains unclear and vary over the lifespan of the individual [22].

PWS is a multisystem disorder characterized by severe hypotonia with poor suck and feeding difficulties in early infancy and followed by excessive eating at later infancy or early childhood, thus gradually developing morbid obesity [23]. Hypogonadism has been observed in both males and females and manifested as genital hypoplasia and incomplete pubertal development [23].

PWS occurs as the result of absence of expression of paternal genes from chromosome 15q11.2-q13 due to genomic imprinting and are normally active only from the paternally contributed chromosome 15 [23]. The absence of expression of one or more of the paternally inherited genes has been reported to contribute to the observed phenotype of PWS [23]. The major mechanism contributing this phenomena are; (i) deletion of a 5-6 $\mathrm{Mb}$ region from the paternally contributed chromosome 15 (found in $65-75 \%$ of affected individuals) (ii) maternal uniparental disomy (UPD) 15 (found in 20-30\%) and (iii) a defect in the genomic region that controls the imprinting process, a so-called imprinting defect (ID; $1-3 \%$ ) [23].

\subsection{Angelman Syndrome}

Angelman Syndrome (AS) was first described by Dr. Harry Angelman in 1965 [24]. It was characterized by developmental delay, absent speech, ataxic gait, seizures and a distinctive behavioural phenotype with excitability and paroxysms of laughter [24]. The incidence has been reported to be $1 / 12,000$ to $1 / 20,000[25,26]$. AS is caused by disruption of the function of the maternally inherited ubiquitin-protein ligase E3A (UBE3A) gene within the 15q11-q13 region [27-31]. This region spans approximately $120 \mathrm{~kb}$ of genomic DNA and contains 16 exons with coding region of $60 \mathrm{~kb}$ [24].

In normal neurons, $U B E 3 A$ is transcriptionally inactivated on the paternally derived allele of chromosome 15 and is active only on the maternally derived allele [24]. The syndrome occurs due to 4 different mutational mechanisms affecting the maternally derived chromosome 15: intragenic mutation, deletion of the gene, paternal UPD with absence of maternal chromosome 15 and a defect in the imprinting center that controls UBE3A transcription [24]. In imprinting inheritance, offspring of carrier mothers are theoretically at $50 \%$ risk of having AS [31].

\subsection{2q11.2 Deletion syndrome}

Di George/ VeloCardio Facial Syndrome (DG/VCFS) are caused by a deletion at 22q11.2 [3]. DG/VCFS has been reported as the most common microdeletion syndrome, with an estimated incidence of 1 in 4000 births [3]. Tomita-Mitchell and colleagues reported that 22q11.2 DS which is also known as DiGeorge syndrome type 1 (DGS1) is the most prevalent inheritable genetic deletion syndrome [32]. The common features of this syndrome are congenital heart disease, cleft palate, velopharyngeal insufficiency with hypernasal speech, hypocalcaemia, dysmorphic facial features and mild to moderate mental retardation, with a high variability in the number and severity of associated features [33]. Individuals with 22q11.2 DS often experience recurrent infections caused by problems with the immune system, and some develop autoimmune disorders such as rheumatoid arthritis and Graves' disease [34]. 
Congenital heart defects are present in approximately $75 \%$ of patients with 22q11.2DS and typically constitutes conotruncal malformations such as interrupted aortic arch type $\mathrm{B}$, truncus arteriosus communis, tetralogy of Fallot and pulmonary atresia with ventricular septal defect [35]. Although psychotic disorders among 22q11.2DS patients is high with about 1 in every 5 patients, non psychotic conditions has also been reported to be more prevalent [36]. Van Engelen et al., (2010) also reported that individuals with 22q11.2DS have a $50 \%$ chance of transmitting the deletion to his or her offspring.

$22 \mathrm{q} 11.2$ deletion syndrome is a contiguous gene deletion syndrome inherited in an autosomal dominant manner [37]. About $93 \%$ of probands have a de novo deletion of 22q11.2 and 7\% have inherited the $22 \mathrm{q} 11.2$ deletion from a parent [37, 38]. Meanwhile, offspring of affected individuals have a 50\% chance of inheriting the 22q11.2 deletion. The deletion occurs most often as a random event during the formation of reproductive cells or in early foetal development. Affected individuals usually do not have any history of the disorder in their family, though they can pass the condition to their children. In about $10 \%$ of cases, a person with this condition inherits the deletion in chromosome 22 from a parent. In inherited cases, other family members may be affected as well.

One of the key genes, $T B X 1$, encodes a T-box transcription factor, which is known to have an essential role in early vertebrate development. $T B X 1$ has been suggested as a candidate gene for del22q11.2 syndrome, $T B X 1$ is a recently described member of the T-box gene family that has been conserved throughout metazoan evolution. Other T-box proteins have been identified in various species that have a range of roles in early vertebrate development and aspects of mesoderm specification, including heart and limb development. Three genes from this family have been associated with dominant human disorders. Mutations in TBX3 result in ulnarmammary syndrome. TBX5 mutations cause Holt-Oram syndrome. Mutations in TBX22 lead to cleft palate with ankyloglossia. Therefore, we conclude that $T B X 1$ would be a major genetic determinant of del22q11.2 syndrome in human beings.

\subsection{Williams-Beuren Syndrome}

Williams-Beuren syndrome (WBS) is a neurodevelopmental disorder involving facial appearance characteristics, supravalvular aortic stenosis and mental retardation [39]. WBS has also been presented with a wide collection of symptoms affecting blood vessels, growth, intelligence, and behaviour [39]. Children with this condition have distinctive facial features, a hoarse voice associated with growth, mental retardation and an overfriendly personality; hyperacusis, infantile hypercalcemia, prematurely wrinkled skin are also common symptoms [40].

WBS has been reported to be in 1 in 7,500 live births with no ethnic or sex preference [41, 42] and is caused by a hemizygous contiguous gene microdeletion at 7q11.23 spanning 28 genes [43] . 90 to $95 \%$ of the WBS patients showed $1.55 \mathrm{Mb}$ deletion due to mispairing between the centromeric and medial LCR (Low copy repeats) blocks B (Bcen and Bmid) [44]. Meanwhile 5 to $10 \%$ of cases showed an $~ 1.84-\mathrm{Mb}$ deletion spanning the breakpoints within the centromeric and medial LCR blocks A (Acen and Amid) [45].

The classification of WBS phenotype is largely based on evidences from functional studies of single genes, animal models, and analysis of WBS individuals with atypical deletions [43]. Studies conducted by Antonell and colleagues (2010) concluded that hemizygosity of LIMK1, CLIP2, GTF2IRD1, and GTF2I is associated to the specific WBS cognitive profile and craniofacial features. Meanwhile, another study suggests that reduced BAZ1B protein level has been linked to cardiac, craniofacial, and hypercalcemia defects [46].

\subsection{7q21.31 Microdeletion Syndrome}

17q21.31 was first reported in 2006 with an estimated prevalence of 1 in 13,000 to 20,000 [47]. The $17 \mathrm{q} 21.31$ deletion was reported to occur de novo and the characteristic features include moderate intellectual disability, developmental delay, severe hypotonia, and facial dysmorphisms, especially a long face and tubular or pear-shaped nose [47]. This syndrome also may include epilepsy, anomalies of the central nervous system such as corpus callosum defects and hydrocephalus and congenital abnormalities of heart and kidneys [48]. This microdeletion syndrome is largely due to microtubule-associated protein tau (MAPT) haploinsufficiency which in turn leads to neurodegenerative disorders such as fronto-temporal dementias and progressive supranuclear palsy [48-50]. 
Table 1. Characteristics of the common microdeletion syndromes

\begin{tabular}{|c|c|c|c|}
\hline Syndrome & $\begin{array}{c}\text { Chromosomal } \\
\text { locus }\end{array}$ & $\begin{array}{l}\text { Incidence } \\
\text { (births) }\end{array}$ & Clinical Features \\
\hline $\begin{array}{l}\text { Smith- } \\
\text { Magenis } \\
\text { Syndrome }\end{array}$ & $17 \mathrm{p} 11.2$ & $1 / 25,000$ & $\begin{array}{l}\text { Brachycephaly, a broad face, frontal bossing, synophrys, } \\
\text { hypertelorism, upslanting eyes, midface hypoplasia with } \\
\text { a depressed nasal bridge, a tented upper lip, prognathism, } \\
\text { and low-set or abnormally shaped ears }\end{array}$ \\
\hline $\begin{array}{l}\text { Miller-Dieker } \\
\text { Syndrome }\end{array}$ & $17 \mathrm{p} 13.3$ & $\begin{array}{l}1 / 50,000 \\
\end{array}$ & $\begin{array}{l}\text { Prominent forehead with bitemporal hollowing, short } \\
\text { nose with upturned nares and thickened upper lip with a } \\
\text { thin vermilion upper border, widely spaced eyes, low } \\
\text { ears, and small jaw }\end{array}$ \\
\hline $\begin{array}{l}\text { Prader-Willi } \\
\text { Syndrome }\end{array}$ & $15 q 11.2-q 13$ & $\begin{array}{l}1 / 10,000- \\
1 / 30,000\end{array}$ & $\begin{array}{l}\text { Severe hypotonia with poor suck and feeding difficulties } \\
\text { in early infancy and followed by excessive eating at later } \\
\text { infancy or early childhood, thus gradually developing } \\
\text { morbid obesity }\end{array}$ \\
\hline $\begin{array}{l}\text { Angelman } \\
\text { Syndrome }\end{array}$ & $15 q 11-q 13$ & $\begin{array}{l}1 / 12,000 \\
\quad \text { to } \\
1 / 20,000\end{array}$ & $\begin{array}{l}\text { Developmental delay, absent speech, ataxic gait, seizures } \\
\text { and a distinctive behavioural phenotype with excitability } \\
\text { and paroxysms of laughter }\end{array}$ \\
\hline $\begin{array}{l}22 \mathrm{q} 11.2 \\
\text { Deletion } \\
\text { syndrome }\end{array}$ & $22 q 11.2$ & $1 / 4,000$ & $\begin{array}{l}\text { Congenital heart disease, cleft palate, velopharyngeal } \\
\text { insufficiency with hypernasal speech, hypocalcaemia, } \\
\text { dysmorphic facial features and mild to moderate mental } \\
\text { retardation, with a high variability in the number and } \\
\text { severity of associated features }\end{array}$ \\
\hline $\begin{array}{l}\text { Williams- } \\
\text { Beuren } \\
\text { Syndrome } \\
\end{array}$ & $7 q 11.23$ & $1 / 7,500$ & $\begin{array}{l}\text { Hoarse voice associated with growth, mental retardation } \\
\text { and an overfriendly personality; hyperacusis, infantile } \\
\text { hypercalcemia, prematurely wrinkled skin }\end{array}$ \\
\hline $\begin{array}{l}17 \mathrm{q} 21.31 \\
\text { Microdeletion } \\
\text { Syndrome }\end{array}$ & $17 \mathrm{q} 21.31$ & $\begin{array}{l}1 / 13,000 \\
-1 / \\
20,000\end{array}$ & $\begin{array}{l}\text { Moderate intellectual disability, developmental delay, } \\
\text { severe hypotonia, and facial dysmorphisms, especially a } \\
\text { long face and tubular or pear-shaped nose }\end{array}$ \\
\hline
\end{tabular}

\section{Microdeletion Detection Methods}

Chromosome deletion and microdeletion syndromes account for an increasing number of clinically recognizable genetic conditions. New deletion syndromes continue to be characterized and a number of previously described syndromes are being found to be due to chromosomal deletions or microdeletions. Several molecular genetics methods including multiplex ligation-dependent probe amplification (MLPA), fluorescence in situ hybridization (FISH), quantitative fluorescent PCR (QF-PCR) and microarray-based comparative genomic hybridization (arrayCGH) have been well established for prenatal diagnosis of chromosomal abnormalities in clinical labs [51,52].

\subsection{Multiplex Ligation Dependent Probe Amplification}

MLPA is a variation of the multiplex polymerase chain reaction that permits multiple targets to be amplified with only a single primer pair. Each of the probes consists of two oligonucleotides which recognise adjacent target sites on the DNA with one of the probe containing the sequence recognised by the forward primer, while the other the sequence recognised by the reverse primer [53]. Only when both probe oligonucleotides are hybridised to their respective targets, can they be ligated into a complete probe. Each complete probe has a unique length, so that its resulting amplicons can be separated and identified by (capillary) electrophoresis [53].

\subsection{Fluorescent In Situ Hybridization}

FISH technologies are in wide clinical use to diagnose deletion and microdeletion syndromes [54]. Future uses of these technologies will provide prognostic information for patients and their parents, as the genes responsible for the phenotypic aspects of various deletion syndromes are identified [54]. The technique of FISH is based on the same principle as any DNA hybridization method that uses the ability of single-stranded DNA to anneal to complementary DNA [55]. In the case of FISH, the target DNA, which may be metaphase chromosomes, interphase nuclei or tissue sections, is attached to a glass microscope slide [55]. The development of a complete set of unique FISH clones near the junction of subtelomeric sequences of each chromosome arm allowed a targeted analysis of all human telomeres to identify cryptic deletions, duplications, and unbalanced translocations [56]. The advantage of FISH is its improved speed and spatial resolution, labelled probes are stable and can be stored over long periods, and the possibility of detection of multiple targets simultaneously in different colours [55]. 


\subsection{Sequencing}

Although the above mentioned testing methods have been proved to be highly reliable, the major limitation remains restricted resolution and limited coverage on the human genome at one time [57, 58]. To overcome these limitations, studies have been focussing on sequencing techniques in detection of microdeletions $[59,60]$. With the application of third-generation sequencing system in clinical laboratories, such as Miseq/Illumina and Ion Torrent PGM/Life Technologies, the whole process takes less time with acceptable price [59]. Thus, it is likely that massively parallel sequencing (MPS) will play an increasingly important role in the future development of prenatal screening and diagnosis [59].

\subsection{Quantitative Fluorescent PCR}

QF-PCR, which is based on the amplification of chromosome-specific DNA short-tandem-repeat (STR) polymorphisms. This technique employs fluorescnt primers to detect peaks on a DNA sequencer . Normal heterozygous subjects are expected to show two peak areas (peaks ratio $1: 1$ ) for each locus analyzed, while trisomies are visualized either as an extra peak (triallelic) or as a $2: 1$ ratio between the peak areas for two peaks at a given locus. Besides this, recent reports involving large numbers of patients have clearly demonstrated the clinical efficacy of QF-PCR in the detection of aneuploidy [61-63].

\subsection{Microarray-based Comparative Genomic Hybridization}

Bejjani and Shaffer [64] described microarray-based comparative genomic hybridization (array CGH) as a revolutionary platform that was recently adopted in the clinical laboratory, which allows a high-resolution evaluation of DNA copy number alterations associated with chromosome abnormalities. Array CGH has many research applications including cancer profiling, gene discovery, and understanding epigenetic modifications and chromatin conformation [64].

Array CGH is also widely being applied in detection of copy number changes in a resolution of even as low as $1 \mathrm{~Kb}$ [65]. ISCA (International Standard Cytogenomic Array) Consortium supports the use of array CGH as a first-line test and suggests reserving chromosomal G-banding analysis for specific cases like patients with obvious chromosomal syndromes such as Down syndrome and family history of chromosomal rearrangements [65]. The high resolution afforded by array CGH has been used to define candidate regions for putative genes responsible for human genetic diseases [64]. Vissers and colleagues [66] proved this by hybridizing cell lines from two individuals with CHARGE syndrome onto a genome-wide array with a 1-Mb resolution.

The primary advantage of array CGH over fluorescence in situ hybridization (FISH) is its ability to detect DNA copy changes such as deletions, duplications, or amplifications, simultaneously at multiple loci in a genome [64].

\section{Conclusion}

Although one or few genes have been reported to have a greater impact, it is the cumulative effect of the imbalance of several other genes in the deletion that determines the overall phenotype and the presence of additional genetic and environmental modifiers may also contribute to the variability in the observed phenotypes of these syndromes. Adding to this, early diagnosis and comprehensive care of these patients in recent years has increased radically thus enabling a better insight into these eminent syndromes. This further facilitates an accurate understanding of the genome and potential gene therapies, which then leads towards the detection of mutations with important role in various areas of genetic diagnosis including pre-implantation genetic diagnosis (PGD), prenatal diagnosis (PND), pre-symptomatic testing, conformational diagnosis and forensic/identity testing [67]. Furthermore, the application of array CGH has created a paradigm shift in genetics that has moved the description and discovery of genetic conditions from the "phenotype-first" approach, in which patients exhibiting similar clinical features are identified prior to the discovery of an underlying aetiology, to a "genotype-first" approach, in which a collection of individuals with similar copy-number imbalances can be examined for common clinical features [68]. The importance of cytogenetics in these syndromes has paved way to the exploration into the developmental pathways in a functional approach which further aids in identification of many new microdeletion syndromes.

\section{Acknowledgements}

This review has been supported by the Universiti Sains Malaysia Short Term Grant 304/PPSG/61312032.

\section{REFERENCES}

[1] L.G. Shaffer, D.H. Ledbetter, and J.R. Lupski, Molecular cytogenetics of contiguous gene syndromes: mechanisms and consequences of gene dosage imbalance, in Scriver C.R., Beaudet A.L., Sly W.S., and Valle D., (Ed.) The Metabolic \& Molecular Bases of Inherited Disease, (McGraw-Hill, Medical Publishing Division, 2001) 1291.

[2] G.L. Carvill and H.C. Mefford, Microdeletion syndromes, Current Opinions in Genetics and Developmets, 2013. 
[3] S. Schwartz and M.D. Graf, Microdeletion syndromes. Characteristics and diagnosis, Methods in Molecular Biology, 204, 2002, 275-290.

[4] M. Teraoka and K. Narahara, [Smith-Magenis syndrome], Ryoikibetsu Shokogun Shirizu, (15), 1996, $224-226$.

[5] F. Greenberg, V. Guzzetta, R. Montes de Oca-Luna, R.E. Magenis, A.C. Smith, S.F. Richter, I. Kondo, W.B. Dobyns, P.I. Patel, and J.R. Lupski, Molecular analysis of the Smith-Magenis syndrome: a possible contiguous-gene syndrome associated with del(17)(p11.2), American journal of human genetics, 49(6), 1991, 1207-1218.

[6] A.C. Smith, L. McGavran, J. Robinson, G. Waldstein, J. Macfarlane, J. Zonona, J. Reiss, M. Lahr, L. Allen, and E. Magenis, Interstitial deletion of (17)(p11.2p11.2) in nine patients, American journal of medical genetics, 24(3), 1986, $393-414$.

[7] R.E. Slager, T.L. Newton, C.N. Vlangos, B. Finucane, and S.H. Elsea, Mutations in RAI1 associated with Smith-Magenis syndrome, Nature genetics, 33(4), 2003, 466-468.

[8] K.S. Chen, P. Manian, T. Koeuth, L. Potocki, Q. Zhao, A.C. Chinault, C.C. Lee, and J.R. Lupski, Homologous recombination of a flanking repeat gene cluster is a mechanism for a common contiguous gene deletion syndrome, Nature genetics, 17(2), 1997, 154163.

[9] L. Potocki, C.J. Shaw, P. Stankiewicz, and J.R. Lupski, Variability in clinical phenotype despite common chromosomal deletion in Smith-Magenis syndrome [del(17)(p11.2p11.2)], Genetics in Medicine, 5(6), 2003, 430-434.

[10] C.N. Vlangos, D.K. Yim, and S.H. Elsea, Refinement of the Smith-Magenis syndrome critical region to approximately 950kb and assessment of 17p11.2 deletions. Are all deletions created equally?, Mol Molecular Genetics and Metaolism, 79(2), $2003,134-141$.

[11] W. Bi, J. Yan, P. Stankiewicz, S.S. Park, K. Walz, C.F. Boerkoel, L. Potocki, L.G. Shaffer, K. Devriendt, M.J. Nowaczyk, K. Inoue, and J.R. Lupski, Genes in a refined Smith-Magenis syndrome critical deletion interval on chromosome 17p11.2 and the syntenic region of the mouse, Genome Research, 12(5), 2002, 713-728.

[12] A.C. Smith, A.L. Gropman, J.E. Bailey-Wilson, O. Goker-Alpan, S.H. Elsea, J. Blancato, J.R. Lupski, and L. Potocki, Hypercholesterolemia in children with Smith-Magenis syndrome: del (17) (p11.2p11.2), Genetics in medicine : official journal of the American College of Medical Genetics, 4(3), 2002, 118-125.

[13] N. Liburd, M. Ghosh, S. Riazuddin, S. Naz, S. Khan, Z. Ahmed, Y. Liang, P.S. Menon, T. Smith, A.C. Smith, K.S. Chen, J.R. Lupski, E.R. Wilcox, L. Potocki, and T.B. Friedman, Novel mutations of MYO15A associated with profound deafness in consanguineous families and moderately severe hearing loss in a patient with Smith-Magenis syndrome, Human genetics, 109(5), 2001, 535-541.

[14] L. Potocki, D. Glaze, D.X. Tan, S.S. Park, C.D. Kashork, L.G. Shaffer, R.J. Reiter, and J.R. Lupski, Circadian rhythm abnormalities of melatonin in Smith-Magenis syndrome, Journal of medical genetics, 37(6), 2000, 428-433.

[15] P.H. King, R. Waldrop, J.R. Lupski, and L.G. Shaffer, Charcot-Marie-Tooth phenotype produced by a duplicated PMP22 gene as part of a 17p trisomy-translocation to the X chromosome, Clinical genetics, 54(5), 1998, 413-416.

[16] B. Finucane, Haas-Givler,B, Smith-Magenis Syndrome: Genetic Basis and Clinical Implications, International Journal of Mental Health, (2), 2009, 134-148.

[17] J. Yingling, K. Toyo-Oka, and A. Wynshaw-Boris, Miller-Dieker syndrome: analysis of a human contiguous gene syndrome in the mouse, The American Journal of Human Genetics, 73(3), 2003, 475-488.

[18] W.B. Dobyns, C.J. Curry, H.E. Hoyme, L. Turlington, and D.H. Ledbetter, Clinical and molecular diagnosis of Miller-Dieker syndrome, The American Journal of Human Genetics, 48(3), 1991, 584-594.

[19] S.C. Nagamani, F. Zhang, O.A. Shchelochkov, W. Bi, Z. Ou, F. Scaglia, F.J. Probst, M. Shinawi, C. Eng, J.V. Hunter, S. Sparagana, E. Lagoe, C.T. Fong, M. Pearson, M. Doco-Fenzy, E. Landais, M. Mozelle, A.C. Chinault, A. Patel, C.A. Bacino, T. Sahoo, S.H. Kang, S.W. Cheung, J.R. Lupski, and P. Stankiewicz, Microdeletions including YWHAE in the Miller-Dieker syndrome region on chromosome $17 \mathrm{p} 13.3$ result in facial dysmorphisms, growth restriction, and cognitive impairment, Journal of medical genetics. 46(12), 2009, 825-833.

[20] H. Ueda, T. Sugiura, S. Takeshita, K. Ito, H. Kakita, R. Nagasaki, K. Kurosawa, and S. Saitoh, Combination of Miller-Dieker syndrome and VACTERL association causes extremely severe clinical presentation, European journal of pediatrics, 2013.

[21] J.E. Emerick and K.S. Vogt, Endocrine manifestations and management of Prader-Willi syndrome, International journal of pediatric endocrinology, (1), 2013, 14.

[22] R.A. Harrington, D.A. Weinstein, and J.L. Miller, Hypoglycemia in Prader-Willi syndrome, American journal of medical genetics. Part A, 2014.

[23] S.B. Cassidy, S. Schwartz, J.L. Miller, and D.J. Driscoll, Prader-Willi syndrome, Genetics in Medicine, 14(1), 2012, 10-26.

[24] A. Dagli, K. Buiting, and C.A. Williams, Molecular and Clinical Aspects of Angelman Syndrome, Molecular syndromology. 2(3-5), 2012, 100-112.

[25] J. Clayton-Smith and M.E. Pembrey, Angelman syndrome, Journal of medical genetics. 29(6), 1992, $412-415$.

[26] S. Steffenburg, C.L. Gillberg, U. Steffenburg, and M. Kyllerman, Autism in Angelman syndrome: a population-based study, Pediatric neurology, 14(2), 1996, 131-136.

[27] T. Kishino, M. Lalande, and J. Wagstaff, UBE3A/E6-AP mutations cause Angelman syndrome, Nature Genetics, 15(1), 1997, 7073.

[28] T. Matsuura, J.S. Sutcliffe, P. Fang, R.J. Galjaard, Y.H. Jiang, C.S. Benton, J.M. Rommens, and A.L. Beaudet, De novo truncating mutations in E6-AP ubiquitin-protein ligase gene (UBE3A) in Angelman syndrome, Nature Genetics, 15(1), $1997,74-77$.

[29] Y. Jiang, E. Lev-Lehman, J. Bressler, T.F. Tsai, and A.L. Beaudet, Genetics of Angelman syndrome, The American Journal of Human Genetics, 65(1), 1999, 1-6.

[30] R.D. Nicholls and J.L. Knepper, Genome organization, function, and imprinting in Prader-Willi and Angelman syndromes, Annual review of Genomics and Human Genetics, 2, 2001, 153-175.

[31] A.K. Panda, S.K. Kar, and G. Gopinath, Angelman syndrome in three biological siblings: Focusing on the neuropsychiatric domain, Journal of pediatric neurosciences, 8(3), 2013, 213-216.

[32] A. Tomita-Mitchell, D.K. Mahnke, J.M. Larson, S. Ghanta, Y. Feng, P.M. Simpson, U. Broeckel, K. Duffy, J.S. Tweddell, W.J. Grossman, J.M. Routes, and M.E. Mitchell, Multiplexed quantitative real-time PCR to detect 22q11.2 deletion in patients with congenital heart disease, Physioogical Genomics, 42A(1), 2010, 52-60.

[33] L. Ziolkowska, W. Kawalec, A. Turska-Kmiec, M. Krajewska-Walasek, G. Brzezinska-Rajszys, J. Daszkowska, B. Maruszewski, and P. Burczynski, Chromosome 22q11.2 microdeletion in children with conotruncal heart defects: frequency, associated cardiovascular anomalies, and outcome following cardiac surgery, Europian Journal of Peadiatrics, 167(10), 2008, 1135-1140.

[34] K. van Engelen, A. Topf, B.D. Keavney, J.A. Goodship, E.T. van der Velde, M.J. Baars, S. Snijder, A.F. Moorman, A.V. Postma, and B.J. Mulder, 22q11.2 Deletion Syndrome is under-recognised in adult patients with tetralogy of Fallot and pulmonary atresia, Heart, 96(8), 2010, 621-624. 
[35] D.M. McDonald-McGinn, R. Kirschner, E. Goldmuntz, K. Sullivan, P. Eicher, M. Gerdes, E. Moss, C. Solot, P. Wang, I. Jacobs, S. Handler, C. Knightly, K. Heher, M. Wilson, J.E. Ming, K. Grace, D. Driscoll, P. Pasquariello, P. Randall, D. Larossa, B.S. Emanuel, and E.H. Zackai, The Philadelphia story: the 22q11.2 deletion: report on 250 patients, Journal of Genetic Counseling, 10(1), 1999, 11-24.

[36] W.L. Fung, R. McEvilly, J. Fong, C. Silversides, E. Chow, and A. Bassett, Elevated prevalence of generalized anxiety disorder in adults with 22q11.2 deletion syndrome, The American journal of psychiatry, 167(8), 2010, 998.

[37] D.M. McDonald-McGinn, M.K. Tonnesen, A. Laufer-Cahana, B. Finucane, D.A. Driscoll, B.S. Emanuel, and E.H. Zackai, Phenotype of the 22q11.2 deletion in individuals identified through an affected relative: cast a wide FISHing net!, Genetics in medicine : official journal of the American College of Medical Genetics, 3(1), 2001, 23-29.

[38] A.S. Bassett, D.M. McDonald-McGinn, K. Devriendt, M.C. Digilio, P. Goldenberg, A. Habel, B. Marino, S. Oskarsdottir, N. Philip, K. Sullivan, A. Swillen, and J. Vorstman, Practical guidelines for managing patients with 22q11.2 deletion syndrome, The Journal of pediatrics, 159(2), 2011, 332-339.

[39] R.L. Dutra, R.S. Honjo, L.D. Kulikowski, F.M. Fonseca, P.C. Pieri, F.S. Jehee, D.R. Bertola, and C.A. Kim, Copy number variation in Williams-Beuren syndrome: suitable diagnostic strategy for developing countries, BMC Research Notes, 5, $2012,13$.

[40] C.A. Morris, S.A. Demsey, C.O. Leonard, C. Dilts, and B.L. Blackburn, Natural history of Williams syndrome: physical characteristics, Journal of Pediatics, 113(2), 1988, 318-326.

[41] P. Stromme, P.G. Bjornstad, and K. Ramstad, Prevalence estimation of Williams syndrome, Journal of Child Neurology, 17(4), 2002, 269-271.

[42] C.A. Morris, I.T. Thomas, and F. Greenberg, Williams syndrome: autosomal dominant inheritance, American Journal of Medical Genetics, 47(4), 1993, 478-481.

[43] C. Fusco, L. Micale, B. Augello, M. Teresa Pellico, D. Menghini, P. Alfieri, M. Cristina Digilio, B. Mandriani, M. Carella, O. Palumbo, S. Vicari, and G. Merla, Smaller and larger deletions of the Williams Beuren syndrome region implicate genes involved in mild facial phenotype, epilepsy and autistic traits, European journal of human genetics : EJHG, 22(1), 2014, 64-70.

[44] R. Peoples, Y. Franke, Y.K. Wang, L. Perez-Jurado, T. Paperna, M. Cisco, and U. Francke, A physical map, including a BAC/PAC clone contig, of the Williams-Beuren syndrome--deletion region at 7q11.23, American Journal of Medical Genetics, 66(1), 2000, 47-68.

[45] M. Bayes, L.F. Magano, N. Rivera, R. Flores, and L.A. Perez Jurado, Mutational mechanisms of Williams-Beuren syndrome deletions, American Journal of Medical Genetics, 73(1), 2003, 131-151.

[46] G.B. Ferrero, C. Howald, L. Micale, E. Biamino, B. Augello, C. Fusco, M.G. Turturo, S. Forzano, A. Reymond, and G. Merla, An atypical 7q11.23 deletion in a normal IQ Williams-Beuren syndrome patient, European journal of human genetics : EJHG, 18(1), 2010, 33-38.

[47] J.I. Egger, E. Wingbermuhle, W.M. Verhoeven, M. Dijkman, S. Radke, E.R. de Bruijn, B. de Vries, R.P. Kessels, and D. Koolen, Hypersociability in the behavioral phenotype of $17 \mathrm{q} 21.31$ microdeletion syndrome, American journal of medical genetics, Part A, $161 \mathrm{~A}(1), 2013,21-26$.

[48] D.A. Koolen, A.J. Sharp, J.A. Hurst, H.V. Firth, S.J. Knight, A. Goldenberg, P. Saugier-Veber, R. Pfundt, L.E. Vissers, A. Destree, B. Grisart, L. Rooms, N. Van der Aa, M. Field, A. Hackett, K. Bell, M.J. Nowaczyk, G.M. Mancini, P.J. Poddighe, C.E. Schwartz, E. Rossi, M. De Gregori, L.L. Antonacci-Fulton, M.D. McLellan, 2nd, J.M. Garrett, M.A. Wiechert, T.L. Miner, S. Crosby, R. Ciccone, L. Willatt, A. Rauch, M. Zenker, S. Aradhya, M.A. Manning, T.M. Strom, J. Wagenstaller, A.C. Krepischi-Santos, A.M. Vianna-Morgante, C. Rosenberg, S.M. Price, H. Stewart, C. Shaw-Smith, H.G. Brunner, A.O. Wilkie, J.A. Veltman, O. Zuffardi, E.E. Eichler, and B.B. de Vries, Clinical and molecular delineation of the 17q21.31 microdeletion syndrome, Journal of medical genetics, 45(11), 2008, 710-720.

[49] A.J. Myers, M. Kaleem, L. Marlowe, A.M. Pittman, A.J. Lees, H.C. Fung, J. Duckworth, D. Leung, A. Gibson, C.M. Morris, R. de Silva, and J. Hardy, The H1c haplotype at the MAPT locus is associated with Alzheimer's disease, Human molecular genetics, 14(16), 2005, 2399-2404.

[50] T.M. Caffrey and R. Wade-Martins, Functional MAPT haplotypes: bridging the gap between genotype and neuropathology, Neurobiology of disease, 27(1), 2007, 1-10.

[51] E.S. Williams, M.N. Cornforth, E.H. Goodwin, and S.M. Bailey, CO-FISH, COD-FISH, ReD-FISH, SKY-FISH, Methods in Molecular Biology, 735, 2011, 113-124.

[52] T.Y. Leung, I. Vogel, T.K. Lau, W. Chong, J.A. Hyett, O.B. Petersen, and K.W. Choy, Identification of submicroscopic chromosomal aberrations in fetuses with increased nuchal translucency and apparently normal karyotype, Ultrasound in obstetrics \& gynecology : the official journal of the International Society of Ultrasound in Obstetrics and Gynecology, 38(3), 2011, 314-319.

[53] J.P. Schouten, C.J. McElgunn, R. Waaijer, D. Zwijnenburg, F. Diepvens, and G. Pals, Relative quantification of 40 nucleic acid sequences by multiplex ligation-dependent probe amplification, Nucleic Acids Researsc, 30(12), 2002, e57.

[54] S.K. Shapira, An update on chromosome deletion and microdeletion syndromes, Current Opinion in Pediatrics, 10(6), $1998,622-$ S.K. 627 .

[55] E. Garimberti and S. Tosi, Fluorescence in situ hybridization (FISH), basic principles and methodology, Methods in Moecular Biology, 659, 2010, 3-20.

[56] E.L. Baldwin, J.Y. Lee, D.M. Blake, B.P. Bunke, C.R. Alexander, A.L. Kogan, D.H. Ledbetter, and C.L. Martin, Enhanced detection of clinically relevant genomic imbalances using a targeted plus whole genome oligonucleotide microarray, Genetics in medicine : official journal of the American College of Medical Genetics, 10(6), 2008, 415-429.

[57] J.R. Vermeesch, H. Fiegler, N. de Leeuw, K. Szuhai, J. Schoumans, R. Ciccone, F. Speleman, A. Rauch, J. Clayton-Smith, C. Van Ravenswaaij, D. Sanlaville, P.C. Patsalis, H. Firth, K. Devriendt, and O. Zuffardi, Guidelines for molecular karyotyping in constitutional genetic diagnosis, European journal of human genetics : EJHG, 15(11), 2007, 1105-1114.

[58] ACOG Practice Bulletin No. 88, December 2007. Invasive prenatal testing for aneuploidy, Obstetrics and gynecology, 110(6), 2007, 1459-1467.

[59] S. Dan, F. Chen, K.W. Choy, F. Jiang, J. Lin, Z. Xuan, W. Wang, S. Chen, X. Li, H. Jiang, T.Y. Leung, T.K. Lau, Y. Su, W. Zhang, and X. Zhang, Prenatal detection of aneuploidy and imbalanced chromosomal arrangements by massively parallel sequencing, PloS one, 7(2), 2012, e27835.

[60] T.J. Jensen, Z. Dzakula, C. Deciu, D. van den Boom, and M. Ehrich, Detection of microdeletion 22q11.2 in a fetus by nextgeneration sequencing of maternal plasma, Clinical chemistry, 58(7), 2012, 1148-1151.

[61] B. Pertl, S. Kopp, P.M. Kroisel, L. Tului, B. Brambati, and M. Adinolfi, Rapid detection of chromosome aneuploidies by quantitative fluorescence PCR: first application on 247 chorionic villus samples, Journal of medical genetics, 36(4), 1999, 300-303. 
[62] W. Schmidt, J. Jenderny, K. Hecher, B.J. Hackeloer, S. Kerber, L. Kochhan, and K.R. Held, Detection of aneuploidy in chromosomes X, Y, 13, 18 and 21 by QF-PCR in 662 selected pregnancies at risk, Molecular human reproduction, 6(9), 2000, 855860 .

[63] M. Adinolfi and J. Sherlock, Prenatal detection of chromosome disorders by QF-PCR, Lancet. 358(9287), $2001,1030-1031$.

[64] B.A. Bejjani and L.G. Shaffer, Application of array-based comparative genomic hybridization to clinical diagnostics, The Journal of molecular diagnostics : JMD, 8(5), 2006, 528-533.

[65] P. Evangelidou, A. Alexandrou, M. Moutafi, M. Ioannides, P. Antoniou, G. Koumbaris, I. Kallikas, V. Velissariou, C. Sismani, and P.C. Patsalis, Implementation of high resolution whole genome array $\mathrm{CGH}$ in the prenatal clinical setting: advantages, challenges, and review of the literature, Biomed Research International, 2013.

[66] L.E. Vissers, C.M. van Ravenswaaij, R. Admiraal, J.A. Hurst, B.B. de Vries, I.M. Janssen, W.A. van der Vliet, E.H. Huys, P.J. de Jong, B.C. Hamel, E.F. Schoenmakers, H.G. Brunner, J.A. Veltman, and A.G. van Kessel, Mutations in a new member of the chromodomain gene family cause CHARGE syndrome, Nature genetics, 36(9), 2004, 955-957.

[67] N. Mahdieh and B. Rabbani, An Overview of Mutation Detection Methods in Genetic Disorders, Iranian journal of pediatrics, 23(4), 2013, 375-388.

[68] L.G. Shaffer, A. Theisen, B.A. Bejjani, B.C. Ballif, A.S. Aylsworth, C. Lim, M. McDonald, J.W. Ellison, D. Kostiner, S. Saitta, and T. Shaikh, The discovery of microdeletion syndromes in the post-genomic era: review of the methodology and characterization of a new 1q41q42 microdeletion syndrome, Genetics in medicine : official journal of the American College of Medical Genetics, 9(9), 2007, 607-616. 